\title{
ANALISIS KEPERCAYAAN PUBLIK TERHADAP KEBIJAKAN VAKSINASI COVID-19 DI KOTA SURABAYA
}

\author{
'Arimurti Kriswibowo, ${ }^{2}$ Josephine Karina Putri Prameswari, ${ }^{3}$ Alif Galih Baskoro \\ 1,2,3 Program Studi Ilmu Administrasi Publik UPN Veteran Jawa Timur \\ arimurti.adne@upnjatim.ac.id \\ Surabaya, 60294, Indonesia
}

\begin{abstract}
Vaccination should be one of the solutions for handling the Covid-19 outbreak, but in fact there are still many people who doubt and even don't believe it, so this creates conflict between the government and the community. The aim of this study is to determine the extent of public confidence in the Covid-19 vaccination policy made by the government so that the acceleration of handling Covid-19 can be achieved. The research method used is descriptive analysis with a quantitative approach and data collection techniques using a questionnaire. The sample in this study was taken from the population of the city of Surabaya. The sample is divided into 5 community clusters, namely students, state civil servants (ASN), health workers, education personnel and the civil society. This research is limited to an unknown sample so that the determination of the number of samples is set to be 100 respondents. The results of this study indicate that the level of public trust from the five clusters in the Covid-19 vaccination policy is in the trust category, which means that the level of public compliance with the Covid-19 vaccination policy is also high. This can be a consideration for the government to increase its efforts to build relationships with the community so that it will gain the trust of the community.
\end{abstract}

\section{Keywords: Covid-19; Public trust; Public policy; Surabaya}

\begin{abstract}
Abstrak
Vaksinasi seharusnya menjadi salah satu solusi untuk penanganan wabah Covid-19 namun pada kenyataan nya masih banyak masyarakat yang meragukan bahkan tidak percaya sehingga hal ini menimbulkan konflik antara pemerintah dan masyarakat. Tujuan dari penelitian ini adalah untuk mengetahui sejauh mana kepercayaan publik terhadap kebijakan vaksinasi Covid-19 yang dibuat oleh pemerintah agar percepatan penanganan Covid-19 tercapai. Metode penelitian yang digunakan adalah analisis deskriptif dengan pendekatan kuantitatif dan teknik pengumpulan data menggunakan kuisioner. Sampel dalam penelitian ini diambil dari populasi masyarakat Kota Surabaya. Sampel tersebut dibagi pada 5 kluster masyarakat, yakni Mahasiswa, Aparatur Sipil Negara (ASN), tenaga kesehatan, tenaga pendidikan dan masyarakat umum. Penelitian ini terbatas pada sampel yang belum diketahui sehingga penentuan jumlah sampel ditetapkan menjadi 100 responden. Hasil penelitian ini menunjukkan bahwa tingkat kepercayaan masyarakat dari kelima cluster tersebut terhadap kebijakan vaksinasi Covid-19 masuk dalam kategori percaya, yang artinya tingkat kepatuhan masyarakat terhadap kebijakan vaksinasi Covid-19 juga tinggi. Hal ini dapat menjadi pertimbangan bagi pemerintah untuk meningkatkan usaha pembangunan relasi dengan masyarakat sehingga memperoleh kepercayaan dari masyarakat.
\end{abstract}

Keywords: Covid-19; Kebijakan publik; Kepercayaan Publik; Surabaya

Open Access at:http://ojs.uho.ac.id/index.php/PUBLICUHO/index

Journal Publicuho is licensed under a Creative Commons Attribution 4.0 International License. 


\section{Journal Publicuho}

ISSN2621-1351 (online), ISSN 2685-0729 (print)

Volume 4 Number 2 (May-July), (2021)pp. 326-344

Accredited SINTA SK.NOMOR 28/E/KPT/2019

Open Access at:http://ojs.uho.ac.id/index.php/PUBLICUHO/index

DOI: 10.35817/jpu.v4i2.17912

\section{PENDAHULUAN}

Dilansir dalam laman (World Health Organization, 2020) Coronavirus adalah suatu kelompok virus yang dapat menyebabkan penyakit pada hewan atau manusia. Beberapa jenis coronavirus diketahui menyebabkan infeksi saluran nafas pada manusia mulai dari batuk pilek hingga yang lebih serius seperti Middle East Respiratory Syndrome (MERS) dan Severe Acute Respiratory Syndrome (SARS). Kasus Covid-19 mulai merebak di Indonesia pada Maret 2020 lalu. Pada awal kasus ini merebak, pemerintah Indonesia terkesan merespon Covid-19 secara lamban dan tidak praktis, hal ini terkait dengan pembuatan kebijakan yang dibutuhkan dalam menangani virus ini serta implementasinya sebagai upaya untuk meminimalisir dampak dari pandemi ini terhadap kesehatan masyarakat dan ekonomi (Nugroho \& Negara, 2020).

Jumlah kasus Covid-19 kian meningkat hari demi hari, Jawa Timur menjadi salah satu provinsi dengan kasus terbanyak (peringkat 4) dan Kota Surabaya menjadi kota dengan kasus terbanyak di Provinsi Jawa Timur. Menurut data yang diunggah oleh (Official, 2021), jumlah kasus Covid-19 di Jawa Timur per 7 April 2021 berada pada angka 138,706 kasus. Menurut laman (Covid-19, 2021) jumlah kasus Covid-19 di Kota Surabaya yang terkonfirmasi per 7 April 2021 mencapai angka 22,397 kasus. Bertambahnya jumlah kasus masih belum berbanding lurus dengan usaha usaha penangannya. Hal ini berakibat pada relasi yang dimiliki antara pemerintah dengan masyarakat khususnya dalam komitmen penyelesaian rantai virus ini. Masyarakat mulai mempertanyakan keseriusan dan kesigapan pemerintah dalam usaha penanganan Covid-19.

Dalam kondisi darurat kesehatan saat ini, yang paling dibutuhkan masyarakat adalah kebijakan sebagai intervensi pemerintah. Kebijakan merupakan salah satu hasil dari kekuasaan dan kewenangan yang dimiliki oleh pemerintah dalam usaha mewujudkan tercapainya tujuan negara. Masyarakat membutuhkan adanya ketegasan dan keteladanan pemerintah dalam mengimplementasikan kebijakan penanganan Covid-19 yang telah dibuat. Dalam mengimplementasikan sebuah kebijakan, tentunya kebijakan itu sendiri memiliki sejumlah unsur penting yang berkaitan dengan kepentingan negara dan masyarakat, hal ini menjelaskan bahwa salah satu landasan penting dalam sebuah pengimplementasian kebijakan publik ialah kepercayaan publik.

Menurut Moorman yang dikutip oleh (Ningtyas, 2018), kepercayaan diartikan sebagai bentuk keinginan untuk menyandarkan diri pada sebuah hubungan dengan pihak lain dengan berlandaskan keyakinan. Atau juga dipahami sebagai harapan yang dapat dimiliki oleh siapa saja untuk dapat mengandalkan pihak lain terutama melalui setiap kata yang diucapkan. Tidak dapat dihindari bahwa kredibilitas juga mempengaruhi tingkat kepercayaan. Kredibilitas dapat menjadi salah satu faktor utama yang mempengaruhi 
seseorang untuk memiliki rasa percaya karena kredibilitas ditunjukkan melalui kemampuan atau keahlian khusus dalam melakukan sesuatu, sehingga kepercayaan yang timbul bersifat organik dan didapat melalui cara yang baik dalam sebuah hubungan. Bukan hanya kredibilitas, hal lain yang dapat mempengaruhi tingkat kepercayaan seseorang iala reliabilitas dan intensionalitas.

Menurut (Lijeblad et al., 2009), terdapat beberapa dimensi yang dapat digunakan sebagai indikator untuk menghitung tingkat kepercayaan. (1) Dimensi Share Norms and Value meliputi responsiveness, integrity, compassion and understanding, worthy of pride, (2) Dimensi Willingness to Endorse meliputi trustworthy, (3) Dimensi Percieved Efficacy meliputi effectiveness dan reliability. Pada dimensi Share Norms and Valve, kepercayaan diukur atau dinilai dari responsivitas, integritas dan kepedulian pemerintah terhadap masyarakat melalui kebijakan yang dibuat. Sedangkan dimensi Willingness to Endorse memberikan indikator penilaian kepercayaan yang dapat dibangun melalui kinerja, perilaku maupun kebijakan yang dapat memberikan alasan bagi masyarakat untuk mempercayai pemerintah. Terakhir, dimensi Percieved Efficacy memberikan pemahaman bahwa kepercayaan masyarakat terhadap pemerintah maupun kebijakan yang dibuat ialah melaui efektivitas kinerja pemerintah atau kebijakan yang dibuat dan keandalan pemerintah dalam mengatasi masalah-masalah dalam masyarakat.

Hasil penelitian yang dilakukan oleh (Widaningrum, 2017), menunjukkan bahwa masyarakat percaya pemerintah mampu menjalankan perannya sebagai pengelola kegiatan pemerintahan. Sehingga dapat disimpulkan bahwa kepercayaan publik ialah suatu kondisi dimana masyarakat mempercayai kemampuan pemerintah dalam menjalankan perannya sebagai pengelola kegiatan pemerintahan. Kompetensi dan kapabilitas pemerintah saat ini dapat ditunjukkan melalui keseriusan dan komitmen terhadap penanganan Covid-19, salah satunya ialah dengan membuat kebijakan serta program yang mendorong percepatan penanganan Covid-19.

Kebijakan Publik memiliki berbagai definisi. Bridgeman seperti yang dikutip oleh (TUWU, 2020) mendefinisikan kebijakan sebagai "whatever government choose to do or not to do". Pernyataan tersebut berarti kebijakan publik merupakan segala sesuatu yang pemerintah pilih untuk dilakukan maupun tidak dilakukan. Sehingga dapat dipahami bahwa kebijakan ialah sebuah hal yang ditetapkan oleh pemerintah yang bertujuan mengarahkan dan memberikan pilihan untuk bertindak secara terencana dan konsisten untuk menjawab masalah publik maupun mencapai tujuan tertentu. Dalam kondisi krisis kesehatan seperti sekarang ini, tidak semua pemimpin publik mampu menunjukkan kemampuan kepemimpinan yang memadai, padahal pemimpin publik seharusnya dapat membuat kebijakan untuk mencapai common good, hal ini dapat menyebabkan terjadinya krisis kepercayaan baik terhadap sistem maupun pemerintah itu sendiri. 


\section{Journal Publicuho}

ISSN2621-1351 (online), ISSN 2685-0729 (print)

Volume 4 Number 2 (May-July), (2021)pp. 326-344

Accredited SINTA SK.NOMOR 28/E/KPT/2019

Open Access at:http://ojs.uho.ac.id/index.php/PUBLICUHO/index

DOI: 10.35817/jpu.v4i2.17912

Lebih lanjut, kebijakan publik dapat di ukur jika di implementasikan. Hal ini sealan dengan pemikiran Jones (1991) dalam La Ode Muhammad Elwan, (2011: 18) menjelaskan bahwa Implementasi kebijakan mudah dimengerti secara teoritik dan konseptual, namun tidak senantiasa demikian dalam bentuknya yang kongkrit, karena pelaksanaannya secara nyata bukanlah sesuatu yang mudah (Supriadin et al., 2020)

Amara Raksasataya dalam (Taufiqurokhman, 2014) mengartikan kebijakan sebagai suatu taktik dan strategi yang diarahkan untuk mencapai suatu tujuan. Oleh karena itu, suatu kebijakan memuat 3 (tiga) elemen yaitu:

a. identifikasi dari tujuan yang ingin dicapai;

b. taktik atau strategi dari berbagai langkah untuk mencapai tujuan yang diinginkan;

c. penyediaan berbagai input untuk memungkinkan pelaksanaan secara nyata dari taktik atau strategi.

Dari beberapa pendapat para ahli diatas dapat di simpulkan bahwa kebijakan publik adalah suatu kegiatan yang dilakukan oleh seorang individu atau suatu kelompok dalam hal ini menitik beratkan pada pemerintah sebagai suatu kerangka kerja yang memiliki tujuan tertentu untuk memecahkan suatu permasalahan yang terjadi di sekitar mereka serta di harapkan hasil dari pelaksanaan kebijakan publik tersebut berdampak ataupun memiliki manfaat kepada sasaran dari kebijakan publik tersebut. Kebijakan publik sendiri mengatur kehidupan orang banyak bukan hanya mementingkan kepentingan pribadi maupun kelompok.

Kepercayaan publik terhadap kebijakan publik tentu dipengaruhi oleh banyak faktor, salah satunya adalah kemampuan pemerintah dalam mengimplementasikan kebijakan yang dibuatnya sebagai bukti kapabilitas pemerintah dalam menjawab berbagai masalah publik yang ada. Implementasi dapat dipahami sebagai perwujudan atau bentuk realisasi rancangan-rancangan yang telah disusun, jika dilakukan secara baik dan tepat akan berpengaruh baik pula terhadap tujuan yang telah ditetapkan, namun jika tidak maka akan menimbulkan masalah-masalah maupun kendala dalam usaha pencapaian tujuan yang telah ditetapkan. Implementasi meliputi berbagai tindakan yang dilaksanakan sesuai dengan rencana yang telah dirancang bersama baik dalam instansi pemerintah, swasta dan lainnya (Hertati \& Arif, 2018).

Vaksinasi seharusnya menjadi salah satu upaya percepatan penanganan Covid-19, hal ini tertuang dalam Peraturan Menteri Kesehatan Republik Indonesia Nomor 84 Tahun 2020 Tentang Pelaksanaan Vaksinasi Dalam Rangka Penanggulangan Pandemi Corona Virus Disease 2019 (Covid-19). Kebijakan ini dibuat dalam rangka usaha pemenuhan kebutuhan rakyat Indonesia terhadap jaminan kesehatan selama pandemic Covid-19. Komite Penasihat 
Ahli Imunisasi Nasional memberikan beberapa rekomendasi terhadap upaya vaksinasi di Indonesia, diantaranya:

1. Vaksinasi Covid-19 di saat pandemi merupakan upaya "Public Goods" yang dilakukan Pemerintah sebagai urusan wajib (Obligatory Public Health Functions). Oleh karena itu seluruh biaya vaksinasi harus ditanggung sepenuhnya oleh pemerintah.

2. Untuk mempercepat penurunan pandemi diperlukan cakupan imunisasi sebesar $70 \%$ agar 'herd immunity' segera tercapai dalam kurun waktu kurang dari 1 tahun.

3. Vaksinasi Covid-19 harus mencakup kelompok usia lanjut (>60 tahun) yang merupakan kelompok risiko tinggi terinfeksi Covid-19 dengan mortalitas yang juga tinggi.

4. Pelayanan vaksinasi dilaksanakan melalui fasilitas Kesehatan pemerintah ataupun swasta yang telah ditunjuk dan memenuhi standar

Pada kenyataannya Pemerintah masih terkesan belum siap dalam prosesnya. Terdapat sejumlah kontroversi yang timbul akibat disinformasi perihal vaksinasi Covid-19. Keraguan oleh masyarakat muncul, keamanan vaksin yang digunakan dipertanyakan hingga apakah jenis vaksin yang digunakan oleh Pejabat Negara akan sama dengan yang digunakan oleh masyarakat pun dipertanyakan. Hal ini menunjukkan kekritisan kepercayaan masyarakat terhadap kebijakan-kebijakan yang hadir sebagai usaha percepatan penanganan Covid-19, salah satunya ialah kebijakan Vaksinasi Covid-19, padahal Denhardt (Ningtyas, 2018) menyatakan bahwa membangun hubungan yang baik serta mendapatkan kepercayaan masyarakat adalah hal yang sangat penting bagi instansi publik, sehingga akan secara langsung berdampak pada kebijakan yang dihasilkan

Dari latar belakang diatas, tulisan ini bermaksud untuk menganalisis kepercayaan publik terhadap kebijakan Vaksinasi Covid-19 yang dibuat untuk mendorong percepatan penanganan Covid-19 oleh pemerintah. Analisis yang dilakukan akan ditinjau melalui dimensi kepercayaan publik yang diungkapkan oleh (Lijeblad et al., 2009) yakni (1) Dimensi Share Norms and Value, (2) Dimensi Willingness to Endorse, (3) Dimensi Percieved Efficacy. Untuk mengukur tingkat kepercayaan publik terhadap kebijakan Vaksinasi Covid-19 akan ditinjau pula melalui elemen kebijakan publik yang diungkapkan oleh Raksasataya dalam (Taufiqurokhman, 2014) yakni (1) identifikasi dari tujuan yang ingin dicapai; (2) taktik atau strategi dari berbagai langkah untuk mencapai tujuan yang diinginkan; (2)penyediaan berbagai input untuk memungkinkan pelaksanaan secara nyata dari taktik atau strategi.

\section{METODOLOGI}

Penelitian ini menerapkan metode kuantitatif dengan menggunakan pendekatan deskriptif. Penelitian kuantitatif sendiri merupakan metode penelitian yang dilakukan secara sistematis, terencana dan terstruktur (Sugiyono, 2012). Sedangkan menurut (Cresswell, 2019) penelitian kuantitatif adalah metode penelitian yang digunakan untuk menguji teori dengan meneliti 


\section{Journal Publicuho}

ISSN2621-1351 (online), ISSN 2685-0729 (print)

Volume 4 Number 2 (May-July), (2021)pp. 326-344

Accredited SINTA SK.NOMOR 28/E/KPT/2019

Open Access at:http://ojs.uho.ac.id/index.php/PUBLICUHO/index

DOI: 10.35817/jpu.v4i2.17912

hubungan antara variabel yang diukur dengan instrumen penelitian yang merupakan angka-angka untuk selanjutnya dianalisis menggunakan prosedur statistik. Adapun pemahaman penelitian deskriptif menurut (Sugiyono, 2012) adalah metode analisis data dengan menggambarkan atau menjelaskan data yang telah dianalisis menggunakan prosedur statistik sebagai mana adanya.

Populasi dalam penelitian ini adalah masyarakat Kota Surabaya yang jumlahnya tidak diketahui sehingga penentuan jumlah sampel ditetapkan menjadi 100 responden, kemudian penulis membagi responden melalui clustered sampling dengan tujuan untuk mengklasifikasikan masyarakat Surabaya dalam berbagai kluster, jumlah masing-masing kluster dapat dilihat dalam tabel 1.

Tabel 1. Kluster dan jumlah responden

\begin{tabular}{clc}
\hline No & \multicolumn{1}{c}{ Kluster } & Jumlah Responden \\
\hline 1. & Mahasiswa & 20 \\
\hline 2. & ASN (Aparatur Sipil Negara) & 20 \\
\hline 3. & Tenaga Kesehatan & 20 \\
\hline 4. & Tenaga Pendidikan & 20 \\
\hline 5. & Masyarakat umum & 20 \\
\hline
\end{tabular}

Sumber: Prameswari, dkk. 2020

Kelima kluster masyarakat tersebut dilandasi oleh beberapa alasan, pemilihan kluster mahasiswa sebagai salah satu klulster responden penelitian ialah mahasiswa merupakan masyarakat dengan usia produktif yang berpikir kritis dan berintelektual sehingga dapat memberikan sumbangsih berupa saran dan feedback terhadap kebijakan publik. Kluster kedua ialah ASN atau Aparatur sipil negara, ASN yang adalah sebagai salah satu target utama kebijakan vaksinasi Covid-19 agar kegiatan pelayanan publik dapat berjalan sebagaimana mestinya. Berikutnya Pemilihan tenaga kesehatan sebagai salah satu kluster lainnya ialah karena tenaga kesehatan sebagai garda terdepan dalam upaya percepatan penanganan Covid-19 yang juga adalah salah satu target utama kebijakan vaksinasi Covid19. Pemilihan kluster tenaga pendidik ialah karena tenaga pendidik sebagai salah satu target utama kebijakan vaksinasi agar kegiatan pendidikan di Indonesia dapat berjalan kembali seperti sedia kala. Yang terakhir ialah kluster masyarakat awam, dengan berbagai profesi, masyarakat awam dianggap bergantung pada usaha/upaya pemerintah dalam penanganan pandemi Covid-19. Operasional variabel terdapat pada tabel 2: 
Tabel 2. Operasionalisasi Variabel

\begin{tabular}{|c|c|c|c|}
\hline No & Variabel & Dimensi & Indikator \\
\hline 1. & & Willingness to endorse & $\begin{array}{ll}\text { - } & \text { Responsiveness } \\
\text { - } & \text { Integrity } \\
\text { - } & \text { Compassion and understanding } \\
\text { - Worthy of pride }\end{array}$ \\
\hline 2. & $\begin{array}{l}\text { Kepercayaan } \\
\text { Masyarakat }\end{array}$ & Share norms and values & - Trustworthy \\
\hline 3. & & Perceived efficiency & $\begin{array}{ll}\text { - } & \text { Effectiveness } \\
\text { - } & \text { Reliability }\end{array}$ \\
\hline
\end{tabular}

Sumber: (Lijeblad et al., 2009)

Dalam penelitian ini menggunakan pengujian validitas dan uji reliabilitas. Instrumen yang baik harus memenuhi dua syarat yaitu validitas dan reliabilitas. Suatu alat ukur yang tidak reliabel atau tidak valid akan menghasilkan kesimpulan yang bias, sehingga akan kurang sesuai dengan yang seharusnya, serta akan memberikan informasi yang keliru mengenai keadaan subjek atau individu yang sedang diuji. Apabila informasi yang keliru itu dengan sadar atau tidak dengan sadar digunakan sebagai dasar pertimbangan dalam pengambilan suatu keputusan, maka keputusan itu tentu menjadi suatu keputusan yang tidak tepat (Bryman, 2004 dalam (Siyoto \& Sodik, 2015)).

Uji validitas data dilakukan dengan menggunakan korelasi Product Moment Pearson dengan rumus sebagai berikut:

$r=\frac{n\left(\sum X Y\right)-\left(\sum X\right) \cdot\left(\sum Y\right)}{\sqrt{\left\{n \cdot \sum X^{2}-\left(\sum X\right)^{2}\right\} \cdot\left\{n \cdot \sum Y^{2}-\left(\sum Y\right)^{2}\right\}}}$

(Siyoto \& Sodik, 2015), Keterangan:

$r \quad$ : Koefisien validitas butir pernyataan yang dicari

n : Banyaknya responden

$\mathrm{X} \quad$ : Skor yang diperoleh subjek dari seluruh item

Y : Skor total yang diperoleh dari seluruh item

$\sum X \quad$ : Jumlah skor dalam kontribusi $X$

$\sum Y \quad$ : Jumlah skor dalam kontribusi $Y$

$\Sigma X^{2} \quad$ : Jumlah kuadrat masing-masing $X$

$\Sigma Y^{2} \quad$ : Jumlah kuadrat masing-masing $Y$

Ukuran reliabilitas dalam penelitian ini dilakukan dengan mengukur Cronbach's Alpha. Sekaran dan Bougie menyatakan suatu instrumen dikatakan reliabel apabila memiliki nilai Cronbach's Alpha sebesar lebih dari 0,6. Adapun rumus Alpha Cronbach sebagai berikut (Sekaran \& Bougie, 2016): 


\section{Journal Publicuho}

ISSN2621-1351 (online), ISSN 2685-0729 (print)

$$
r_{i}=\left[\frac{k}{k-1}\right]-\left[1-\frac{\sum \sigma^{2} b}{\sigma^{2} t}\right]
$$

Keterangan:

ri : Koefisien reliabilitas alpha

k : : Banyaknya butir pernyataan

$\Sigma \sigma 2 b \quad$ : Jumlah varian butir

$\sum \sigma 2 t \quad$ : Varians total

Teknik analisis data dalam penelitian ini menggunakan metode garis kontinum. Riduwan memaparkan bahwa garis kontinum adalah garis yang digunakan untuk menganalisa, mengukur dan menunjukkan seberapa besar tingkat kekuatan variabel yang sedang diteliti, sesuai instrumen yang digunakan. Model garis kontinum ini menggunakan perhitungan skor yang dijelaskan pada rumus berikut (Riduwan, 2020).

\section{Interval $=$ nilai maksimal - nilai minimal}

\section{jumlah kelas}

Interval $=\frac{5-1}{5}=0,8$

Dari formulasi tersebut dapat ditentukan skala distribusi kriteria pendapat responden sebagaimana dituangkan dalam Tabel 3:

Tabel 3. Rentang Nilai Jawaban Responden

\begin{tabular}{lcc}
\hline No & Rentang Nilai & Kategori \\
\hline 1. & $1,00-1,79$ & Sangat Tidak Percaya \\
\hline 2. & $1,80-2,59$ & Tidak Percaya \\
\hline 3. & $2,60-3,39$ & Kurang Percaya \\
\hline 4. & $3,40-4,19$ & Percaya \\
\hline 5. & $4,20-5,00$ & Sangat Percaya \\
\hline \multicolumn{3}{r}{ Sumber: Hasil penghitungan interval }
\end{tabular}

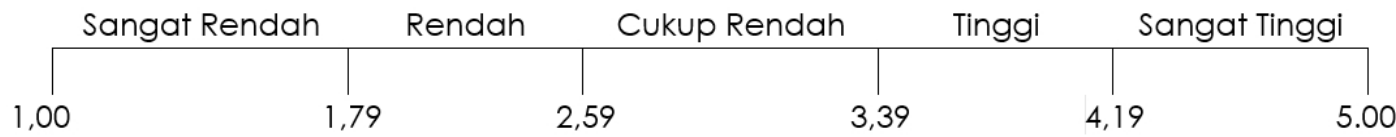

\section{HASIL DAN PEMBAHASAN}

\section{Hasil uji validitas}

Pada tabel 4 memperlihatkan hasil uji validitas kuisioner yang diperoleh dari hasil pengolahan data menggunakan SPSS 
Tabel 4. Hasil uji validitas

\begin{tabular}{ccccc}
\hline & $\begin{array}{c}\text { Scale Mean if } \\
\text { Item Deleted }\end{array}$ & $\begin{array}{c}\text { Scale } \\
\text { Variance if } \\
\text { Item Deleted }\end{array}$ & $\begin{array}{c}\text { Corrected } \\
\text { Item-Total } \\
\text { Correlation }\end{array}$ & $\begin{array}{c}\text { Cronbach's } \\
\text { Alpha if Item } \\
\text { Deleted }\end{array}$ \\
\hline $\mathrm{X} 1.1$ & 21.83 & 10.870 & .407 & .730 \\
\hline $\mathrm{X} 1.2$ & 21.89 & 10.099 & .543 & .705 \\
\hline $\mathrm{X} 1.3$ & 23.45 & 9.058 & .474 & .714 \\
\hline $\mathrm{X} 1.4$ & 23.47 & 8.797 & .552 & .693 \\
\hline $\mathrm{X} 2.1$ & 21.92 & 9.731 & .615 & .690 \\
\hline $\mathrm{X} 3.1$ & 22.57 & 9.035 & .365 & .753 \\
\hline $\mathrm{X} 3.2$ & 22.49 & 9.970 & .429 & .723 \\
\hline \multicolumn{5}{c}{ Sumber: data olahan SPSS 2020 }
\end{tabular}

Pada tabel 4 memuat nilai koefisien validitas yang ditunjukkan dengan nilai corrected item dari setiap pertanyaan. Menurut tingkat signifikansi pada jumlah data 100 dan pada tingkat error $5 \%$, $r$ tabel 0.195, dapat dilihat $r$ hitung kami semua lebih besar daripada $r$ tabel sehingga dapat dikatakan seluruh pernyataan kami valid.

Pada tabel 5 memperlihatkan hasil uji reliabilitas kuisioner yang diolah menggunakan SPSS.

Tabel 5. Hasil Uji Reliabilitas

Cronbach's

$\begin{array}{cc}\text { Alpha } & \text { N of Items } \\ \frac{.746}{\text { Sumber: Data diolah SPSS } 2020}\end{array}$

Berdasarkan hasil uji reliabilitas nilai Cronbach's Alpha. Dapat dilihat nilai Cronbach's Alpha kuisioner kami bernilai 0,746 yang berarti lebih besar dari 0,6. Hal ini membuktikan bahwa alat ukur (kuisioner) yang digunakan dalam penelitian ini reliabel.

\section{Analisis deskriptif responden}

Hasil analisis deskriptif jawaban responden per kluster dengan penentuan kriteria jawaban menggunakan metode garis kontinum dapat dilihat pada tabel 6 sampai dengan 11 .

Tabel 6. Hasil Analisis Deskriptif Tanggapan Responden Kluster Mahasiswa

\begin{tabular}{|c|c|c|c|c|c|c|c|c|c|c|c|}
\hline \multirow[t]{2}{*}{ No } & \multirow[t]{2}{*}{ Pernyataan } & \multirow[t]{2}{*}{ Dimensi } & \multicolumn{5}{|c|}{ Tanggapan } & \multirow{2}{*}{$\begin{array}{c}\text { Total } \\
\text { Respon } \\
\text { den } \\
\end{array}$} & \multirow{2}{*}{$\begin{array}{c}\text { Tota } \\
\text { I } \\
\text { Skor }\end{array}$} & \multirow{2}{*}{$\begin{array}{l}\text { Rata } \\
\text {-rata }\end{array}$} & \multirow[t]{2}{*}{ Kriteria } \\
\hline & & & $\begin{array}{l}\text { ST } \\
\text { S }\end{array}$ & TS & KS & $S$ & SS & & & & \\
\hline 1. & $\begin{array}{l}\text { saya mendukung program } \\
\text { vaksinasi sebagai upaya } \\
\text { pencegahan dan } \\
\text { penuntasan Covid-19 yang } \\
\text { dilakukan oleh pemerintah } \\
\text { (Pernyataan 1) }\end{array}$ & & 0 & 0 & 0 & 13 & 7 & 20 & 87 & 4,35 & $\begin{array}{l}\text { Sangat } \\
\text { percaya }\end{array}$ \\
\hline 2. & $\begin{array}{l}\text { menurut saya kebijakan } \\
\text { vaksinasi menunjukkan } \\
\text { kapabilitas pemerintah } \\
\text { dalam upaya percepatan } \\
\text { penanganan Covid-19 } \\
\text { (Pernyataan 2) }\end{array}$ & $\begin{array}{l}\text { Willingness } \\
\text { to endorse }\end{array}$ & 0 & 1 & 1 & 10 & 8 & 20 & 85 & 4,25 & $\begin{array}{l}\text { Sangat } \\
\text { percaya }\end{array}$ \\
\hline 3. & $\begin{array}{l}\text { menurut saya pejabat } \\
\text { pemerintah mampu }\end{array}$ & & 1 & 0 & 13 & 6 & 0 & 20 & 64 & 3,2 & $\begin{array}{l}\text { Kurang } \\
\text { percaya }\end{array}$ \\
\hline
\end{tabular}




\section{Journal Publicuho}

ISSN2621-1351 (online), ISSN 2685-0729 (print)

Volume 4 Number 2 (May-July), (2021)pp. 326-344

Accredited SINTA SK.NOMOR 28/E/KPT/2019

Open Access at:http://ojs.uho.ac.id/index.php/PUBLICUHO/index

DOI: 10.35817/jpu.v4i2.17912

\begin{tabular}{|c|c|c|c|c|c|c|c|c|c|c|c|}
\hline & $\begin{array}{l}\text { mengimplementasikan } \\
\text { kebijakan vaksinasi Covid-19 } \\
\text { tanpa ada penyelewengan } \\
\text { (Pernyataan 3) }\end{array}$ & & & & & & & & & & \\
\hline 4. & $\begin{array}{l}\text { menurut saya pejabat } \\
\text { pemerintah sudah } \\
\text { mengimplementasikan } \\
\text { kebijakan vaksinasi Covid-19 } \\
\text { secara transparan } \\
\text { (Pernyataan 4) }\end{array}$ & & 2 & 4 & 11 & 3 & 0 & 20 & 55 & 2,75 & $\begin{array}{c}\text { Kurang } \\
\text { percaya }\end{array}$ \\
\hline 5. & $\begin{array}{l}\text { saya percaya terhadap } \\
\text { kebijakan vaksinasi sebagai } \\
\text { upaya percepatan } \\
\text { penanganan Covid-19 oleh } \\
\text { pemerintah (Pernyataan 5) }\end{array}$ & $\begin{array}{l}\text { Share } \\
\text { norms and } \\
\text { values }\end{array}$ & 1 & 0 & 0 & 15 & 4 & 20 & 81 & 4,05 & Percaya \\
\hline 6. & $\begin{array}{l}\text { menurut saya kebijakan } \\
\text { vaksinasi akan mendorong } \\
\text { upaya percepatan } \\
\text { penanganan Covid-19 } \\
\text { secara efektif (Pernyataan 6) }\end{array}$ & & 0 & 3 & 8 & 8 & 1 & 20 & 67 & 3,35 & $\begin{array}{c}\text { Kurang } \\
\text { percaya }\end{array}$ \\
\hline 7. & $\begin{array}{l}\text { menurut saya, pemerintah } \\
\text { menyediakan akses yang } \\
\text { memudahkan masyarakat } \\
\text { dalam memperoleh informasi } \\
\text { mengenai kebijakan vaksinasi } \\
\text { Covid-19 (Pernyataan 7) }\end{array}$ & efficiency & 1 & 0 & 9 & 5 & 5 & 20 & 68 & 3,4 & Percaya \\
\hline
\end{tabular}

Sumber: Kriswibowo, dkk. 2020

Dari tabel 6 dapat dilihat bahwa tingkat kepercayaan masyarakat pada kluster mahasiswa terhadap kebijakan vaksinasi Covid-19 termasuk dalam kategori Percaya

Tabel 7. Hasil Analisis Deskriptif Tanggapan Responden Kluster (ASN)

\begin{tabular}{|c|c|c|c|c|c|c|c|c|c|c|c|}
\hline \multirow[t]{2}{*}{ No } & \multirow[t]{2}{*}{ Pernyataan } & \multirow[t]{2}{*}{ Dimensi } & \multicolumn{5}{|c|}{ Tanggapan } & \multirow{3}{*}{$\begin{array}{c}\text { Total } \\
\text { Responden }\end{array}$} & \multirow{2}{*}{$\begin{array}{l}\text { Total } \\
\text { Skor }\end{array}$} & \multirow{2}{*}{$\begin{array}{l}\text { Rata- } \\
\text { rata }\end{array}$} & \multirow[t]{2}{*}{ Kriteria } \\
\hline & & & STS & TS & KS & $S$ & SS & & & & \\
\hline 1. & (Pernyataan 1) & \multirow{4}{*}{$\begin{array}{l}\text { Willingness to } \\
\text { endorse }\end{array}$} & 0 & 0 & 1 & 15 & 4 & & 83 & 4,15 & Percaya \\
\hline 2. & (Pernyataan 2) & & 0 & 0 & 1 & 16 & 3 & 20 & 82 & 4,1 & Percaya \\
\hline 3. & (Pernyataan 3) & & 2 & 14 & 1 & 3 & 0 & 20 & 45 & 2,25 & $\begin{array}{c}\text { Tidak } \\
\text { percay } \\
\text { a }\end{array}$ \\
\hline 4. & (Pernyataan 4) & & 1 & 13 & 5 & 1 & 0 & 20 & 46 & 2,3 & $\begin{array}{c}\text { Tidak } \\
\text { Percaya }\end{array}$ \\
\hline 5. & (Pernyataan 5) & $\begin{array}{c}\text { Share norms and } \\
\text { values }\end{array}$ & 0 & 0 & 2 & 12 & 6 & 20 & 84 & 4,2 & $\begin{array}{c}\text { Sangat } \\
\text { percay } \\
\text { a }\end{array}$ \\
\hline 6. & (Pernyataan 6) & \multirow{3}{*}{$\begin{array}{l}\text { Perceived } \\
\text { efficiency }\end{array}$} & 2 & 4 & 4 & 3 & 7 & 20 & 69 & 3,45 & Percaya \\
\hline 7. & (Pernyataan 7) & & 0 & 0 & 8 & 11 & 1 & 20 & 73 & 3,65 & Percaya \\
\hline & & & Rata- & tha & & & & & & 3,44 & Percaya \\
\hline
\end{tabular}

Sumber: Kriswibowo dkk.2020

Dari tabel 7 dapat dilihat bahwa tingkat kepercayaan masyarakat pada kluster Aparatur Sipil Negara (ASN) terhadap kebijakan vaksinasi Covid-19 termasuk dalam kategori Percaya. 
ISSN2621-1351 (online), ISSN 2685-0729 (print

Volume 4 Number 2 (May-July-2021) pp.326-344

Arimurti Kriswibowo, et.al

DOI: $10.35817 / j p u . v 4 i 2.17912$

Tabel 8. Hasil Analisis Deskriptif Tanggapan Responden Kluster Tenaga Kesehatan

\begin{tabular}{|c|c|c|c|c|c|c|c|c|c|c|c|}
\hline \multirow[t]{2}{*}{ No } & \multirow[t]{2}{*}{ Pernyataan } & \multirow[t]{2}{*}{ Dimensi } & \multicolumn{5}{|c|}{ Tanggapan } & \multirow{2}{*}{$\begin{array}{c}\text { Total } \\
\text { Responden }\end{array}$} & \multirow{2}{*}{$\begin{array}{l}\text { Total } \\
\text { Skor }\end{array}$} & \multirow{2}{*}{$\begin{array}{l}\text { Rata- } \\
\text { rata }\end{array}$} & \multirow[t]{2}{*}{ Kriteria } \\
\hline & & & STS & TS & $\mathrm{KS}$ & $\mathrm{S}$ & SS & & & & \\
\hline 1. & (Pernyataan 1) & \multirow{4}{*}{$\begin{array}{l}\text { Willingness to } \\
\text { endorse }\end{array}$} & 0 & 0 & 1 & 3 & 16 & 20 & 95 & 4,75 & $\begin{array}{l}\text { Sangat } \\
\text { percaya }\end{array}$ \\
\hline 2. & (Pernyataan 2) & & 0 & 0 & 1 & 5 & 14 & 20 & 93 & 4,65 & $\begin{array}{l}\text { Sangat } \\
\text { percaya }\end{array}$ \\
\hline 3. & (Pernyataan 3) & & 0 & 3 & 12 & 3 & 2 & 20 & 64 & 3,2 & $\begin{array}{l}\text { Kurang } \\
\text { percaya }\end{array}$ \\
\hline 4. & (Pernyataan 4) & & 0 & 4 & 11 & 5 & 0 & 20 & 61 & 3,05 & $\begin{array}{l}\text { Kurang } \\
\text { percaya }\end{array}$ \\
\hline 5. & (Pernyataan 5) & $\begin{array}{l}\text { Share norms } \\
\text { and values }\end{array}$ & 0 & 0 & 1 & 6 & 13 & 20 & 92 & 4,6 & $\begin{array}{l}\text { Sangat } \\
\text { Percaya }\end{array}$ \\
\hline 6. & (Pernyataan 6) & \multirow{2}{*}{$\begin{array}{l}\text { Perceived } \\
\text { efficiency }\end{array}$} & 0 & 0 & 3 & 9 & 8 & 20 & 85 & 4,25 & $\begin{array}{l}\text { Sangat } \\
\text { percaya }\end{array}$ \\
\hline 7. & (Pernyataan 7) & & 0 & 0 & 3 & 14 & 3 & 20 & 80 & 4 & Percaya \\
\hline \multicolumn{8}{|c|}{ Rata-rata } & & & 4,07 & Percaya \\
\hline
\end{tabular}

Sumber: Prameswari dkk. 2020

Dari tabel 8 dapat dilihat bahwa tingkat kepercayaan masyarakat pada kluster tenaga kesehatan terhadap kebijakan vaksinasi Covid-19 termasuk dalam kategori Percaya

Tabel 9. Hasil Analisis Deskriptif Tanggapan Responden Kluster Tenaga Pendidikan

\begin{tabular}{|c|c|c|c|c|c|c|c|c|c|c|c|}
\hline \multirow[t]{2}{*}{ No } & \multirow[t]{2}{*}{ Pernyataan } & \multirow[t]{2}{*}{ Dimensi } & \multicolumn{5}{|c|}{ Tanggapan } & \multirow{2}{*}{$\begin{array}{c}\text { Total } \\
\text { Responden }\end{array}$} & \multirow{2}{*}{$\begin{array}{l}\text { Total } \\
\text { Skor }\end{array}$} & \multirow{2}{*}{$\begin{array}{l}\text { Rata- } \\
\text { rata }\end{array}$} & \multirow[t]{2}{*}{ Kriteria } \\
\hline & & & STS & TS & KS & $S$ & SS & & & & \\
\hline 1. & (Pernyataan 1) & \multirow{4}{*}{$\begin{array}{c}\text { Willingness to } \\
\text { endorse }\end{array}$} & 0 & 0 & 0 & 9 & 11 & 20 & 91 & 4,55 & $\begin{array}{l}\text { Sangat } \\
\text { Percaya }\end{array}$ \\
\hline 2. & (Pernyataan 2) & & 0 & 0 & 1 & 9 & 10 & 20 & 89 & 4,45 & $\begin{array}{l}\text { Sangat } \\
\text { Percaya }\end{array}$ \\
\hline 3. & (Pernyataan 3) & & 2 & 10 & 7 & 1 & 0 & 20 & 47 & 2,35 & $\begin{array}{c}\text { Tidak } \\
\text { percaya }\end{array}$ \\
\hline 4. & (Pernyataan 4) & & 1 & 7 & 9 & 3 & 0 & 20 & 54 & 2,7 & $\begin{array}{l}\text { Kurang } \\
\text { percaya }\end{array}$ \\
\hline 5. & (Pernyataan 5) & $\begin{array}{c}\text { Share norms } \\
\text { and values }\end{array}$ & 0 & 0 & 0 & 10 & 10 & 20 & 90 & 4,5 & $\begin{array}{l}\text { Sangat } \\
\text { Percaya }\end{array}$ \\
\hline 6. & (Pernyataan 6) & \multirow{3}{*}{$\begin{array}{l}\text { Perceived } \\
\text { efficiency }\end{array}$} & 1 & 3 & 7 & 4 & 5 & 20 & 69 & 3,45 & Percaya \\
\hline 7. & (Pernyataan 7) & & 0 & 0 & 6 & 11 & 3 & 20 & 77 & 3,85 & Percaya \\
\hline \multicolumn{7}{|c|}{ Rata-rata } & & & & 3,69 & Percaya \\
\hline
\end{tabular}

Sumber: Prameswari dkk. 2020

Dari tabel 9 dapat dilihat bahwa tingkat kepercayaan masyarakat pada kluster tenaga pendidikan terhadap kebijakan vaksinasi Covid-19 termasuk dalam kategori Percaya

Tabel 10. Hasil Analisis Deskriptif Tanggapan Responden Kluster Masyarakat Awam

\begin{tabular}{|c|c|c|c|c|c|c|c|c|c|c|c|}
\hline \multirow[t]{2}{*}{ No } & \multirow[t]{2}{*}{ Pernyataan } & \multirow[t]{2}{*}{ Dimensi } & \multicolumn{5}{|c|}{ Tanggapan } & \multirow{2}{*}{$\begin{array}{c}\text { Total } \\
\text { Responden }\end{array}$} & \multirow{2}{*}{$\begin{array}{l}\text { Total } \\
\text { Skor }\end{array}$} & \multirow{2}{*}{$\begin{array}{l}\text { Rata- } \\
\text { rata }\end{array}$} & \multirow[t]{2}{*}{ Kriteria } \\
\hline & & & STS & TS & $\mathrm{KS}$ & $S$ & SS & & & & \\
\hline 1. & (Pernyataan 1) & \multirow{4}{*}{$\begin{array}{c}\text { Willingness to } \\
\text { endorse }\end{array}$} & 0 & 0 & 0 & 12 & 8 & 20 & 88 & 4,4 & $\begin{array}{l}\text { Sangat } \\
\text { Percaya }\end{array}$ \\
\hline 2. & (Pernyataan 2) & & 0 & 0 & 0 & 11 & 9 & 20 & 89 & 4,45 & $\begin{array}{l}\text { Sangat } \\
\text { Percaya }\end{array}$ \\
\hline 3. & (Pernyataan 3) & & 1 & 5 & 7 & 5 & 2 & 20 & 62 & 3,1 & $\begin{array}{l}\text { Kurang } \\
\text { percaya }\end{array}$ \\
\hline 4. & (Pernyataan 4) & & 3 & 3 & 5 & 7 & 2 & 20 & 55 & 2,75 & $\begin{array}{l}\text { Kurang } \\
\text { Percaya }\end{array}$ \\
\hline 5. & (Pernyataan 5) & $\begin{array}{c}\text { Share norms } \\
\text { and values }\end{array}$ & 0 & 0 & 0 & 12 & 8 & 20 & 88 & 4,4 & Percaya \\
\hline 6. & (Pernyataan 6) & \multirow{2}{*}{$\begin{array}{l}\text { Perceived } \\
\text { efficiency }\end{array}$} & 1 & 0 & 2 & 12 & 5 & 20 & 80 & 4 & Percaya \\
\hline 7. & (Pernyataan 7) & & 0 & 3 & 1 & 14 & 2 & 20 & 75 & 3,75 & Percaya \\
\hline
\end{tabular}

Sumber: 2020 Prameswari dkk. 2020 


\section{Journal Publicuho}

ISSN2621-1351 (online), ISSN 2685-0729 (print)

Volume 4 Number 2 (May-July), (2021)pp. 326-344

Accredited SINTA SK.NOMOR 28/E/KPT/2019

Open Access at:http://ojs.uho.ac.id/index.php/PUBLICUHO/index

DOI: 10.35817/jpu.v4i2.17912

Dari tabel 10 dapat dilihat bahwa tingkat kepercayaan masyarakat pada kluster masyarakat umum termasuk dalam kategori Percaya

Tabel 11. Hasil Analisis Deskriptif Tanggapan Semua Kluster

\begin{tabular}{cccc}
\hline No & Kluster & Rata-rata skor & kriteria \\
\hline 1 & Mahasiswa & 3,6 & Percaya \\
\hline 2 & Aparatur Sipil Negara (ASN) & 3,44 & Percaya \\
\hline 3 & Tenaga Kesehatan & 4,07 & Percaya \\
\hline 4 & Tenaga Pendidikan & 3,69 & Percaya \\
\hline 5 & Masyarakat Umum & 3,77 & Percaya \\
\hline & Rata-rata & 3,71 & Percaya \\
\hline
\end{tabular}

Sumber: Kriswibowo dkk. 2020

Dari tabel 11 dapat dilihat bahwa tingkat kepercayaan masyarakat pada semua kluster termasuk pada kategori Percaya

\section{PEMBAHASAN}

Pencegahan dan penanggulangan Covid-19 saat ini dilakukan oleh seluruh lapisan masyarakat, tidak peduli siapa, apa dan bagaimana mereka. Pencegahan dan penanggulangan Covid-19 ini semestinya berbasis masyarakat, yang artinya keterlibatan masyarakat dalam proses pencegahan dan penanggulangan pandemi dipengaruhi oleh tingkat kepercayaan dan partisipasi masyarakat.

Dalam Peraturan Menteri Kesehatan Republik Indonesia Nomor 84 Tahun 2020 Tentang Pelaksanaan Vaksinasi Dalam Rangka Penanggulangan Pandemi Corona Virus Disease 2019 (Covid-19) Pasal 8 Ayat (4) menyatakan bahwa prioritas utama penerima vaksin ialah (1) tenaga kesehatan, asisten tenaga kesehatan, tenaga penunjang yang bekerja pada Fasilitas Pelayanan Kesehatan, Tentara Nasional Indonesia, Kepolisian Negara Republik Indonesia, aparat hukum, dan petugas pelayanan publik lainnya; (2) tokoh masyarakat/agama, pelaku perekonomian strategis, perangkat daerah kecamatan, perangkat desa, dan perangkat rukun tetangga/rukun warga; (3) guru/tenaga pendidik dari PAUD/TK, SD, SMP, SMA, atau setingkat/sederajat, dan perguruan tinggi; (4) aparatur kementerian/lembaga, aparatur organisasi perangkat Pemerintah Daerah, dan anggota legislatif; (5) masyarakat rentan dari aspek geospasial, sosial, dan ekonomi; dan (6) masyarakat dan pelaku perekonomian lainnya. Hal ini menjadi salah satu landasan pemilihan kluster responden penelitian ini. 
Pemerintah mengeluarkan kebijakan vaksinasi Covid-19 dengan tujuan mendorong percepatan penanggulangan Covid-19. Dengan hadirnya kebijakan tersebut, peran masyarakat sangat dibutuhkan untuk berkontribusi dalam mengimplementasikan kebijakan tersebut agar tujuan kebijakan vaksinasi Covid-19 dapat tercapai. Faktor utama yang menjadi penyebab keberhasilan sebuah kebijakan ialah keterlibatan masyarakat di dalamnya, yang mana hal tersebut dipengaruhi oleh tingkat kepercayaan masyarakat terhadap kebijakan vaksinasi Covid-19. Artinya masyarakat harus mau mengandalkan kebijakan vaksinasi Covid-19 yang dibuat oleh pemerintah dengan dasar keyakinan agar tujuan mendorong percepatan penanganan Covid-19 dapat tercapai.

Kepercayaan publik, khususnya pada pemerintah sangat berarti bagi efektivitas kinerja pemerintah. Menurut Dwiyanto dalam (Hendiyani, 2019) tingkat kepercayaan publik terhadap pemerintah yang rendah mengakibatkan masyarakat menjadi sulit untuk menerima segala sesuatu yang diinformasikan oleh pemerintah. Dwiyanto juga menyatakan bahwa lebih mudah untuk mengubah kepercayaan secara individu atau per orangan daripada mengubah kepercayaan suatu kelompok. Tingkat keberhasilan kebijakan yang dibuat oleh pemerintah harus selaras dengan tingkat kepercayaan publik, hal ini mengindikasikan bahwa menjalin hubungan yang baik antara pemerintah dan masyarakat ialah penting adanya. Relasi yang baik dapat dibangun dengan melibatkan masyarakat dalam proses perumusan kebijakan itu sendiri, sehingga masyarakat dapat memahami fungsi dan tujuan kebijakan yang dibuat karena masyarakat sendiri yang nantinya akan menerima dampak kebijakan tersebut secara langsung. Keselarasan ini diperlukan agar dalam proses implementasi kebijakan yang ada dapat dijalankan dengan efektif.

Analisis tingkat kepercayaan publik terhadap kebijakan Vaksinasi Covid-19 disajikan melalui tujuh pernyataan sebagai indikator yaitu (1) mendukung program vaksinasi sebagai upaya pencegahan dan penuntasan Covid-19 yang dilakukan oleh pemerintah, (2) mempercayai kebijakan vaksinasi Covid-19 sebagai kapabilitas pemerintah dalam upaya percepatan penanganan Covid-19, (3) mempercayai pejabat pemerintah mampu mengimplementasikan kebijakan vaksinasi Covid-19 tanpa ada penyelewengan, (4) mempercayai bahwa pemerintah telah mengimplementasikan kebijakan vaksinasi Covid-19 secara transparan, (5) mempercayai bahwa kebijakan vaksinasi Covid-19 adalah upaya percepatan penanganan Covid-19 oleh pemerintah, (6) mempercayai bahwa kebijakan vaksinasi Covid-19 akan mendorong percepatan penanganan Covid-19 secara efektif, (7) pemerintah telah memberikan kemudahan dalam mengakses informasi terkait kebijakan vaksinasi Covid-19.

Indikator-indikator tersebut merupakan hasil pemahaman penulis terhadap indikator penilaian kepercayaan publik yang diungkapkan oleh (Lijeblad et al., 2009) (1) Dimensi Share Norms and Value. Dimensi Share norms and values adalah dimensi yang menjelaskan 


\section{Journal Publicuho}

ISSN2621-1351 (online), ISSN 2685-0729 (print)

Volume 4 Number 2 (May-July), (2021)pp. 326-344

Accredited SINTA SK.NOMOR 28/E/KPT/2019

Open Access at:http://ojs.uho.ac.id/index.php/PUBLICUHO/index

DOI: 10.35817/jpu.v4i2.17912

bahwa kepercayaan dibangun berdasarkan gagasan tentang nilai-nilai yang berlaku di komunitas sosial atau lingkungan masyarakat, meliputi responsiveness, integrity, compassion and understanding, worthy of pride, (2) Dimensi Willingness to Endorse, Dimensi Willingness to endorse atau keinginan untuk mendukung ialah sebuah dimensi yang menunjukkan bahwa partisipasi masyarakat sangatlah penting dalam mendorong tingkat kepercayaan publik karena ketika mayoritas masyarakat mendukung tindakan yang dilakukan oleh pemerintah maka lingkungan masyarakat tersebut dapat saling mempengaruhi satu dengan yang lain sehingga mendorong tingkat kepercayaan publik, dimensi ini meliputi trustworthy, (3) Dimensi Percieved Efficacy, Perceived efficacy atau dampak yang dirasakan ialah dimensi yang mengukur tingkat kepercayaan melalui kapasitas atau kemampuan dalam bertindak sehingga dapat menghasilkan dampak sebagai outputnya, dimensi ini meliputi effectiveness dan reliability. Pernyataan 1-4 merupakan indikator dimensi Share Norms and Value, pernyataan 5 merupakan indikator dimensi Willingness to Endorse dan pernyataan 6-7 merupakan indikator dimensi perceived efficacy.

Dimensi Share Norms and Value mencakup 4 indikator utama kepercayaan publik, yang pertama ialah responsiveness atau daya tanggap. Indikator ini mengacu pada kemampuan pemerintah untuk memperhatikan dan beradaptasi dengan kebutuhan serta lingkungan yang terus berubah secara responsif. Saat situasi dan kondisi maupun lingkungan berubah seperti krisis kesehatan saat pandemi ini, menurut hasil penelitian pemerintah dianggap telah mampu mengupayakan percepatan penanganan dan penuntasan rantai Covid-19 melalui kebijakan vaksinasi Covid-19. Hal ini ditunjukkan melalui pernyataan dukungan terhadap kebijakan atau program vaksinasi oleh kelima kluster masyarakat Surabaya.

Yang kedua adalah integrity atau integritas, pejabat pemerintah yang cenderung memiliki sikap jujur, bermoral, dan berkarakter baik dapat lebih mudah atau berpeluang lebih besar untuk dipercaya. Kejujuran, moral serta karakter yang baik ini dapat ditunjukkan melalui keselarasan antara ucapan dengan tindakan. Melalui indikator ini, integritas pemerintah ditunjukkan melalui pembuatan kebijakan vaksinasi Covid-19 sebagai tindakan yang selaras dengan apa yang dijanjikan kepada masyarakat untuk segera memutus rantai penyebaran virus. Dari hasil penelitian yang telah dilakukan, menunjukkan adanya anggapan bahwa pemerintah telah mampu menunjukkan kapabilitasnya dalam menangani krisis kesehatan saat ini melalui pembuatan kebijakan vaksinasi Covid-19 sebagai salah satu upaya mendorong percepatan penanganan Covid-19.

Indikator yang ketiga compassion and understanding atau perasaan simpatik dan keinginan memahami dimaksudkan bahwa pemerintah yang mampu bersimpati, peduli, dan mementingkan kesejahteraan orang banyak dapat memperoleh tingkat kepercayaan 
yang cukup tinggi dari masyarakat. Pemerintah yang mementingkan kesejahteraan warganya mampu melaksanakan atau mengemban tugasnya dengan tanpa melakukan penyelewengan. Dapat dilihat dalam hasil penelitian ini, ditemukan bahwa masyarakat Surabaya kurang percaya terhadap proses implementasi kebijakan vaksinasi Covid-19 oleh pemerintah tanpa adanya peluang penyelewengan. Maka dalam indikator ini, pemerintah dianggap belum mampu mementingkan kesejahteraan masyarakat Surabaya sehingga tidak mendapatkan kepercayaan masyarakat karena masyarakat masih melihat adanya peluang terjadinya penyelewengan.

Indikator keempat adalah worthy of pride atau kelayakan untuk dibanggakan, mengacu kepada pemerintah yang mampu menghargai dan menghormati masyarakat serta memiliki komitmen yang tinggi cenderung mendapatkan kepercayaan publik. Komitmen dan kelayakan pemerintah dalam penelitian ini diukur melalui transparansi implementasi kebijakan vaksinasi Covid-19 yang dilakukan. Masyarakat Surabaya masih kurang percaya terhadap kemampuan pemerintah dalam mengimplementasikan kebijakan vaksinasi Covid-19 secara transparan. Hal ini menunjukkan bahwa pemerintah masih belum mendapatkan kepercayaan dari masyarakat Surabaya melalui indikator ini.

Berikutnya dimensi Willingness to Endorse, indikator terpenting dalam dimensi ini ialah trustworthy behavior, indikator ini mengacu pada sikap pemerintah yang mampu menjamin kepercayaan dengan memiliki alasan untuk dapat dipercayai dengan cara mengklaim bagaimana niat perilaku atau tindakan yang akan dilakukan. Dalam penelitian yang telah dilakukan, ditemukan bahwa masyarakat Surabaya bersedia mendukung kebijakan vaksinasi Covid-19, yang mana hal ini menunjukkan bahwa pemerintah telah mampu bersikap serius dalam upaya percepatan penanganan Covid-19 melalui kebijakan vaksinasi Covid-19 sehingga dapat menjamin dan meningkatkan kepercayaan masyarakat terhadap pemerintah.

Pada dimensi perceived efficacy, Indikator pertama dalam dimensi ini ialah effectiveness atau efektivitas yang mengacu kepada kemampuan pemerintah untuk mencapai tujuan yang ditetapkan dengan sukses, berkeinginan untuk berpengaruh, memenuhi janji, dan hal tersebut dilakukan untuk menjaga kredibilitas. Dalam penelitian ini, ditemukan empat dari kelima kluster masyarakat Surabaya mempercayai bahwa kebijakan vaksinasi Covid-19 dapat mendorong percepatan penanganan Covid-19 secara efektif. Namun pada kluster mahasiswa, didapati bahwa adanya ketidakpercayaan terhadap kebijakan vaksinasi sebagai salah satu upaya mendorong percepatan penanganan Covid19. Hal ini menunjukkan bahwa pemerintah memiliki kredibilitas baik di mata mayoritas masyarakat surabaya kecuali oleh mahasiswa. Mayoritas masyarakat Surabaya menganggap pemerintah telah berusaha dan berupaya memenuhi janji untuk mencapai tujuan yang telah ditentukan, yakni memutus rantai penyebaran Covid-19. 


\section{Journal Publicuho}

ISSN2621-1351 (online), ISSN 2685-0729 (print)

Volume 4 Number 2 (May-July), (2021)pp. 326-344

Accredited SINTA SK.NOMOR 28/E/KPT/2019

Open Access at:http://ojs.uho.ac.id/index.php/PUBLICUHO/index DOI: 10.35817/jpu.v4i2.17912

Indikator berikutnya yakni reliability atau keandalan yakni sebuah indikator kepercayaan publik yang ditinjau dari sejauh mana pemerintah dapat diandalkan untuk melaksanakan fungsi dan bertindak secara konsisten. Pada penelitian ini, keandalan pemerintah dalam melaksanakan fungsinya dan bertindak secara konsisten diukur melalui ketersediaan informasi maupun kemudahan mengakses informasi terkait kebijakan vaksinasi Covid-19 oleh masyarakat Surabaya. Keseluruhan masyarakat Surabaya menyatakan bahwa pemerintah telah dapat diandalkan untuk melaksanakan percepatan penanganan Covid-19 secara menyeluruh melalui pemberian informasi seluas-luasnya.

Dengan adanya tujuh pernyataan tersebut sebagai indikator kepercayaan masyarakat dari masing-masing dimensi terhadap kebijakan vaksinasi Covid-19, ditemukan bahwa secara umum, masyarakat Surabaya mempercayai kebijakan vaksinasi Covid-19 sebagai upaya percepatan penanganan Covid-19 oleh pemerintah. Hal ini terlihat pada tabel 11, yang menunjukkan semua sampel kluster masyarakat Surabaya mempercayai usaha pemerintah dalam memberantas Covid-19 dengan mengelvarkan kebijakan vaksinasi Covid-19. Hal ini sejalan dengan hasil yang ditemukan oleh Edelman Trust Barometer yang menunjukkan bahwa tingkat kepercayaan terhadap pemerintah cukup tinggi.

Gambar 1. Tingkat kepercayaan masyarakat terhadap pemerintah

\section{TRUST IN GOVERNMENT INCREASES IN 18 OF 27 COUNTRIES}
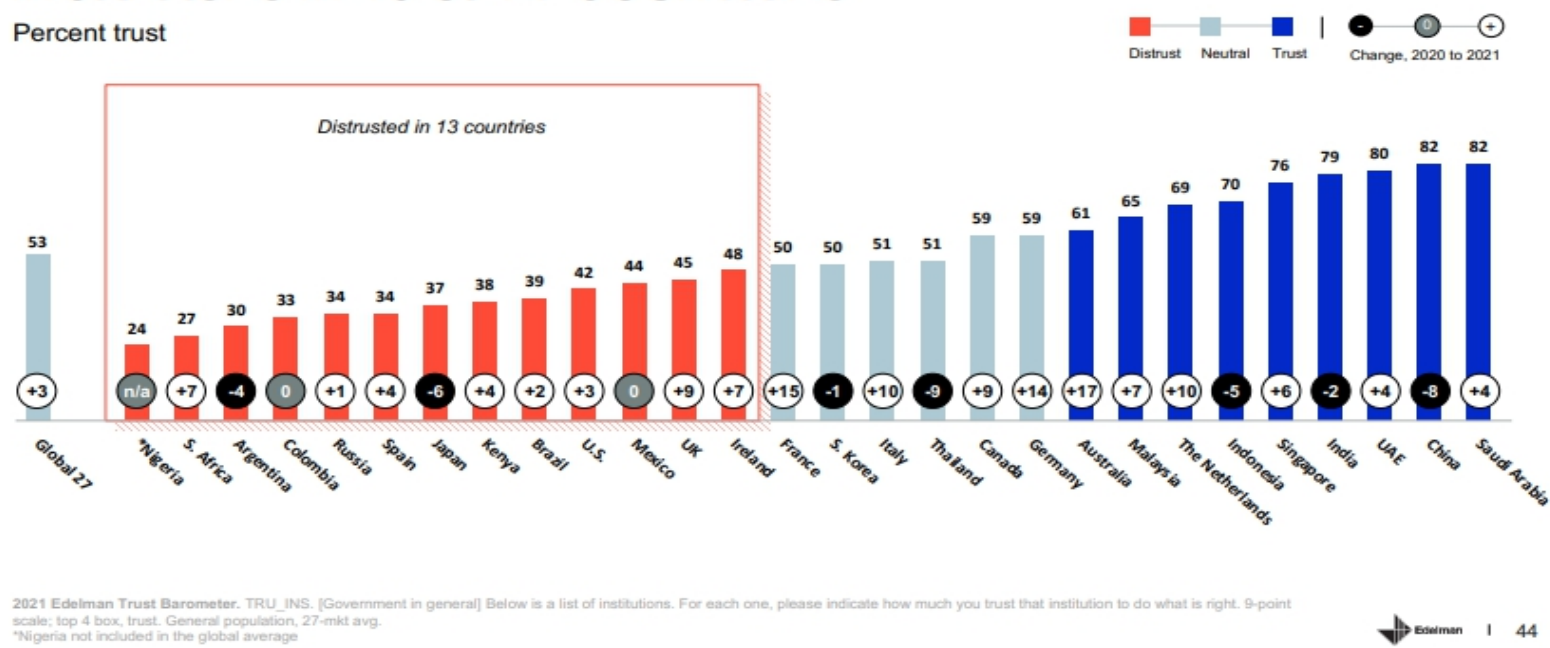

Sumber: Edelman Trust Barometer, 2021.

Dengan data tersebut, dapat diketahui bahwa tingkat kepercayaan masyarakat Indonesia terhadap pemerintah berada pada angka yang cukup tinggi, sehingga seharusnya penerimaan masyarakat terhadap kebijakan yang dikeluarkan pemerintah dapat lebih luas dan mudah diimplementasikan (Hendiyani, 2019). Hal ini membuktikan bahwa masyarakat Surabaya telah mempercayai kebijakan vaksinasi Covid-19 karena 
mereka telah mendukung langkah-langkah pemerintah dalam usaha percepatan penanganan Covid-19, hal ini menyatakan secara tidak langsung bahwa masyarakat Surabaya terlibat dalam usaha percepatan penanganan Covid-19.

(Denhardt, dalam (Ningtyas, 2018) memberikan penjelasan atau pemahaman bahwa ketika pelayanan publik yang mampu diberikan oleh pemerintah mendapatkan apresiasi yang tinggi dari masyarakat maka dapat diindikasikan pemerintah akan mendapatkan kepercayaan yang lebih tinggi dari masyarakat. Pada saat pemerintah mampu menghasilkan kebijakan maupun memberikan pelayanan secara optimal, maka kinerja pemerintah akan diapresiasi oleh masyarakat sehingga kepercayaan publik terhadap pemerintah dapat diperoleh. Hasil penelitian menunjukkan adanya tingkat kepercayaan masyarakat Surabaya yang tinggi terhadap kebijakan vaksinasi Covid-19, maka dapat disimpulkan bahwa pemerintah mampu menghasilkan kebijakan yang mendorong percepatan penanganan Covid-19 secara optimal.

Dari keseluruhan kluster yang ada, tiap-tiap klusternya percaya terhadap kebijakan vaksinasi Covid-19 sebagai upaya percepatan penanganan Covid-19, ini berarti pemerintah sudah mampu menunjukkan kapabilitasnya dalam upaya mendorong percepatan penanganan Covid-19 sehingga dapat diindikasikan upaya ini cukup membantu memperbaiki relasi pemerintah dengan masyarakat Surabaya dalam hal penanganan Covid-19, sehingga dalam implementasinya, kebijakan ini mampu melibatkan masyarakat Surabaya secara menyeluruh.

Hasil penelitian juga mampu menunjukkan bahwa pemerintah sudah mampu mewujudkan harapan masyarakat Surabaya untuk menangani Covid-19 melalui hadirnya kebijakan vaksinasi Covid-19 sehingga masyarakat Surabaya menjadi percaya, dan kembali membangun relasi yang baik dengan pemerintah. Hal ini sejalan dengan pendapat Moorman dalam (Ningtyas, 2018) yang menyatakan bahwa sebuah kepercayaan publik dapat diasumsikan sebagai harapan umum untuk dapat mengandalkan pihak lain, yang dalam penelitian ini pihak lain yang termaksud adalah pemerintah.

Menurut Nugroho dalam (Ryan, 2020) kebijakan publik ada agar dapat memecahkan permasalahan yang terjadi dalam masyarakat. Hal itu dilakukan melalui tiga proses yaitu: merumuskan suatu kebijakan, menerapkan suatu kebijakan serta mengevaluasi suatu kebijakan yang sudah berjalan. Kebijakan Vaksinasi Covid-19 ini dibuat untuk memecahkan permasalahan krisis kesehatan akibat pandemi Covid-19, kebijakan ini dirumuskan berdasarkan pertimbangan usaha atau upaya pencegahan dan penanggulangan Covid-19. Kebijakan ini sudah ditetapkan secara bertahap kepada seluruh lapisan masyarakat dengan mengutamakan masyarakat lansia mulai dari 60 tahun. Dari hasil penelitian yang dilkukan, ditemukan bahwa masyarakat kota Surabaya telah mempercayai kebijakan Vaksinasi Covid-19 sebagai upaya pencegahan dan percepatan 


\section{Journal Publicuho}

ISSN2621-1351 (online), ISSN 2685-0729 (print)

Volume 4 Number 2 (May-July), (2021)pp. 326-344

Accredited SINTA SK.NOMOR 28/E/KPT/2019

Open Access at:http://ojs.uho.ac.id/index.php/PUBLICUHO/index DOI: 10.35817/jpu.v4i2.17912

penanganan Covid-19 oleh pemerintah. Maka dalam mendorong percepatan penanganan Covid-19 di Kota Surabaya sendiri telah berbasis masyarakat karena masyarakat Surabaya menyatakan dukungan terhadap program vaksinasi itu sendiri serta telah menyatakan rasa percayanya kepada kebijakan Vaksinasi Covid-19 sebagai upaya memulihkan kondisi krisis kesehatan saat ini.

\section{KESIMPULAN}

Pemerintah mengeluarkan kebijakan vaksinasi Covid-19 dengan tujuan mendorong percepatan penanggulangan Covid-19. Pencegahan dan penanggulangan Covid-19 ini berbasis masyarakat, yang artinya keterlibatan masyarakat dalam proses pencegahan dan penanggulangan pandemi dipengaruhi oleh tingkat kepercayaan masyarakat. Dalam penelitian ini analisis tingkat kepercayaan publik terhadap kebijakan Vaksinasi Covid-19 disajikan melalui tujuh pernyataan sebagai indikator yaitu mendukung program vaksinasi sebagai upaya pencegahan dan penuntasan Covid-19 yang dilakukan oleh pemerintah, mempercayai kebijakan vaksinasi Covid-19 sebagai kapabilitas pemerintah dalam upaya percepatan penanganan Covid-19, mempercayai pejabat pemerintah mampu mengimplementasikan kebijakan vaksinasi Covid-19 tanpa ada penyelewengan, mempercayai bahwa pemerintah telah mengimplementasikan kebijakan vaksinasi Covid-19 secara transparan, mempercayai bahwa kebijakan vaksinasi Covid-19 adalah upaya percepatan penanganan Covid-19 oleh pemerintah, mempercayai bahwa kebijakan vaksinasi Covid-19 akan mendorong percepatan penanganan Covid-19 secara efektif, pemerintah telah memberikan kemudahan dalam mengakses informasi terkait kebijakan vaksinasi Covid-19. Dengan adanya tujuh pernyataan tersebut sebagai indikator kepercayaan masyarakat terhadap kebijakan vaksinasi Covid-19, ditemukan bahwa masyarakat Surabaya mempercayai kebijakan vaksinasi Covid-19 sebagai upaya percepatan penanganan Covid-19 oleh pemerintah.

\section{REFERENSI}

Anggara, S. (2016). Ilmu Adminsitrasi Negara. CV. Pustaka Setia.

Covid-19, S. L. (2021). Statistik Peta Sebaran Covid-19 Surabaya. https://lawancovid19.surabaya.go.id/visualisasi/graph

Cresswell, J. W. (2019). Research Design: Pendekatan Metode Kualitatif, Kuantitatif dan Campuran (A. Fawaid \& R. K. Pancasari (eds.); Cet. 4). Pustaka Belajar.

Hendiyani, M. F. (2019). Inovasi Pelayanan Publik Di Kota Kreatif Dalam Meningkatkan Kepercayaan Masyarakat Terhadap Pemerintah Di Kota Bandung Provinsi Jawa Barat. TRANSFORMASI: Jurnal Manajemen Pemerintahan, 103-126. https://doi.org/10.33701/jt.v11i1.635 
Hertati, D., \& Arif, L. (2018). Implementasi Kebijakan Pengelolaan Dana Desa di Desa Pejambon Kabupaten Bojonegoro Jawa Timur. Journal of Economics, Business, and Government Challenges, 1 (1), 40-49. https://doi.org/10.33005/ebgc.v1i1.8

Lijeblad, A., Borrie, W. T., \& Watson, A. E. (2009). Determinants of trust for public lands: Fire and fuels management on the bitterroot national forest. Environmental Management, 43(4), 571-584. https://doi.org/10.1007/s00267-008-9230-3

Ningtyas, T. (2018). Kepercayaan Masyarakat (Citizen Trust) Di Badan Pertanahan Nasional (BPN) II Surabaya. Jurnal IImiah Manajemen Publik Dan Kebijakan Sosial, 2(1), 195-211. https://doi.org/10.25139/jmnegara.v2i1.1080

Nugroho, Y., \& Negara, S. D. (2020). Urgent need to strengthen state capacity: Learning from Indonesia's COVID-19 crisis. PERSPECTIVE: Researchers at ISEAS - Yusof Ishak Institute Analyse Current Events, 66, 1-10.

Official, C.-19 I. G. (2021). Peta Sebaran Covid-19. https://covid19.go.id/peta-sebaran Riduwan. (2020). Dasar-dasar Statistika (Cet. 16). Alfabeta.

Ryan, J. (2020). Peranan Jaringan Aktor Dalam Kebijakan Penanganan Covid-19 Di Indonesia. Journal Publicuho, 3(4), 491. https://doi.org/10.35817/jpu.v3i4.15380

Sekaran, U., \& Bougie, R. (2016). Research Methods for Business (7th Editio). John Wiley \& Sons. Siyoto, S., \& Sodik, M. A. (2015). Dasar Metodologi Penelitian Dr. Sandu Siyoto, SKM, M.Kes M. Ali Sodik, M.A. 1. In Dasar Metodologi Penelitian. Literasi Media Publishing.

Sugiyono. (2012). Metodelogi Penelitian Kuantitatif Kualitatif dan R\&D.

Supriadin, R., Alam, S., \& Elwan, L. O. M. (2020). IMPLEMENTASI PERATURAN WALIKOTA KENDARI NOMOR 13 TAHUN 2008 TENTANG PENATAAN PEDAGANG KAKI LIMA DI KOTA KENDARI. Journal Publicuho. https://doi.org/10.35817/jpu.v3i1.11506

Taufiqurokhman. (2014). Kebijakan Publik: PENDELEGASIAN TANGGUNGJAWAB NEGARA KEPADA PRESIDEN SELAKU PENYELENGGARA PEMERINTAHAN. In Kebijakan Publik. Fakultas IImu Sosial Dan IImu Politik Universitas Moestopo Beragama Pers.

Tuwu, D. (2020). Kebijakan Pemerintah Dalam Penanganan Pandemi Covid-19. Journal Publicuho, 3(2), 267. https://doi.org/10.35817/jpu.v3i2.12535

Widaningrum, A. (2017). Public Trust and Regulatory Compliance. Jurnal IImu Sosial Dan IImu Politik, 21 (1), 1.

World Health Organization. (2020). Corona Virus Disease QnA. https://www.who.int/emergencies/diseases/novel-coronavirus-2019/question-andanswers-hub 